\title{
AL-QUR'AN INSIGHTS ABOUT MUSYĀWARĀH (A Study of Maudhu'iy Commentary on Deliberation)
}

\author{
M. Makbul ${ }^{1}$ \\ Achmad Abu Bakar ${ }^{2}$ \\ Aan Parhani ${ }^{3}$ \\ La Ode Ismail Ahmad ${ }^{4}$ \\ Alauddin State Islamic University of Makassar ${ }^{1,2,3,4}$ \\ makbu1013@gmail.com
}

\begin{abstract}
Various kinds of problems occur and have not been able to be resolved in themselves, families, until the nation and state have carried out various ways in an effort to resolve these problems, one of the methods recommended and ordered in the Qur'an is deliberation, what is the nature of deliberation and how the existence, essence and urgency of deliberation will be described in this discussion. This paper attempts to explain these three aspects to give us an idea of the concept of deliberation in the perspective of maudhu'iy. This study will describe the definitions, objects, principles to the benefits of deliberation in the perspective of the Qur'an.
\end{abstract}

Keywords: Maudhu'iy interpretation; Discussion; Quranic Insights.

\section{INTRODUCTION}

The Qur'an is essentially revealed as a guide for humans to draw closer to Him, as we know that in the Qur'an it does not focus more on issues that have not been able to be understood by the mind so that they have not undergone development or change. So from this pattern we understand why the Qur'an will describe things that cannot be reached by the human senses, such as heaven and hell because these are problems that cannot be understood by reason. ${ }^{1}$ Some things will indeed be very difficult for humans to understand if they only rely on their knowledge of the senses and reason alone, because not all things in this world can be sensed, sometimes there are things that can only be believed by faith. ${ }^{2}$ So that human limitations should continue to strengthen our faith if there are still many things that we do not know and can only be known, then it is Allah Swt. who provides instructions in the form of data and explanations about these matters, among some of the most important ones related to eschatology, for example. doomsday, the grave, the mahsyar field to the concept of heaven and hell.

Not only matters related to eschatology that cannot be sensed by humans, but also the topics that are also universally described in it, namely: this matter becomes meaningful considering the urgency of the concept being interpreted, with an explanation that is directly mentioned in the Qur'an. so that it will really help us in an

${ }^{1}$ Said, Muh. "Metodologi Penafsiran Sufistik: Perspektif Al-Gazali." Jurnal Diskursus Islam 2.1 (2014), h. 142-168.

${ }^{2}$ Amir, A., Khalid, M. R., Garancang, S., \& Kasim, A. "Bentuk-Bentuk Takrār dalam Al-Qur'an menurut Tinjauan Balagah (Studi Pada Juz Amma)”. Jurnal Diskursus Islam, 5(3), h. 498-526. 


\section{Al-Qur'an Insights About MusyāWarāH \\ (A Study of Maudhu'iy Commentary on Deliberation)}

effort to understand, understand, describe and implement the universal principles that are the essence of existence and the urgency of this matter including the concept of deliberation. $^{3}$

The question of deliberation will always be dynamic because this is not a matter related to eschatology, but is part of muamalah worship that helps humans in solving various kinds of problems. Allah SWT. bestowing the holy book al-Qur'an which will be a guide that accommodates all matters in general which are of a substance nature, while those which are accidental will be the responsibility of humans to develop them. Including in elaborating the issue of deliberation in the perspective of the Al-Qur'an. Even the Messenger of Allah. In providing benchmarks in deliberation, it is not rigid and explicitly explained. That is why, the method of practicing deliberation on the khalaufrrasidins are: Caliph Abu Bakr, Umar bin Khattab, Usman bin Affan, to Ali bin Abi Talib ra.

If we try to dissect the issue of deliberation, it has been substantively clearly described in the Qur'an, but it is necessary to understand that the explanations, interpretations, descriptions related to the deliberation issue actually come from the explanations of the companions, tabi'in and scholars. Given that it is very important to look at things from a contextual perspective, especially in the case of Deliberation, the researcher considers it important that it is important to reflect on how the Qur'an views deliberation in the review of Maudhu'iy interpretations. Therefore, it is related to the background of the problems that have been described. then the title of the paper that was raised was: Insights of the Qur'an on Deliberation (A Study of Maudhu'iy Interpretation).

\section{DISCUSSION}

In this section, we will describe matters related to the existence, essence and urgency of deliberation:

\section{A. Definition of Deliberation in The Perspective of The Qur'an}

Etymologically the terminology of deliberation is essentially rooted in the character: sy wr, this combination of words means "explaining, stating, taking something". From this word formed: tasyawur (negotiation), asyara (signing), syawir (asking for opinion), tasyaara (exchanging ideas), mustasyiru (asking for the opinion of others), then ontologically all these terms come from the root word, syara, yasyuru, syauran, which means "removing honey from the beehive". ${ }^{4}$ When referring to the opinion of M. Quraish Shihab when viewed in the context of the etymology of the genealogy, it becomes "everything that can be taken or removed from others (including opinions)". ${ }^{5}$ Then al-As \}fahani, explained that the root of the word means "to say or

${ }^{3}$ M. Ka-anga, \& Hamzah, H. Metode Ijtihad Lembaga Majlis Agama Islam Provinsi Pattani Thailand Selatan. Jurnal Diskursus Islam, 7(2), h. 314-334.

${ }^{4}$ Abi al-Husayn Ahmad bin Fâris bin Zakariya', Mu'jam Maqâyis al-Lughât, ditahqîq oleh 'Abd al-Salam Muhammad Haris, IV (Mesir: Mushthafa' al-Bâb al-Halabi wa Awulâduhu', 1975), h. 541.

${ }^{5}$ M. Quraish Shihab, Ensiklopedia alQuran: Kajian Kosakata, Jakarta: Lentera Hati, 2007. h. 966-967. 
propose something". ${ }^{6}$ Therefore, the word deliberation is essentially only used for things that are fine, and is in line with the basic meaning described at the beginning, which is like removing "honey", from the nest. ${ }^{7}$

Referring to the etymological description of terminology and genealogy, it can be elaborated to understand that the word deliberation is closely related to removing honey from the hive. From a philosophical point of view, bees are animals that only take good things from plant juices, when they take them they don't damage their feeding grounds, they take enough without overdoing it. The bee itself also does not attack as long as it does not feel threatened and it is done only to protect themselves. Likewise, taking honey from bees, taking advantage of the honey produced by bees must be done wisely so that the benefits of honey can be obtained without being hurt by the sting. Therefore, deliberation in this term must be carried out wisely to obtain consensus.

Referring to the fiqh perspective, the word deliberation is defined as an attempt to ask the opinion of others, or a group of people related to matters or affairs. In terms of deliberation, it is generally understood as an effort to carry out negotiations, in this case exchanging ideas. ${ }^{8}$ In the Big Indonesian Dictionary, deliberation is "a discussion carried out together in solving problems on the basis of agreement." 9

From some of the perspectives that have been described, in this case deliberation can be concluded that is an effort to discuss something together on a problem by collecting opinions based on various points of view which aims to reach a decision in an effort to solve the problem, so that the problem becomes clear and clear and with good and useful results. In the discussion of this article, we will try to look at the perspective of the Qur'an regarding the term deliberation in accordance with all forms of derivation, from the research conducted, it is found that there are three forms of deliberation, namely: tasyawur, QS al-Baqarah verse 233; syawir, QS Āli 'Imrān verse 159, and shura', QS al-Shura' verse 38.

Therefore, it is important to elaborate the term in terms of the intended verses:

1. Tasyawur in $\mathrm{QS}$ al-Baqarah verse 233

In QS al-Baqarah verse 233 This verse explains about deliberation as a way of making a decision in the household, such as the desire of a mother or father who wants to wean their child or separate the child from his mother (not breastfeeding him) before two years, then both parents must be discussed first. Whether they agree to wean their child or not. If one of the two does not agree to this, then give the child to be breastfed to others they should not do. ${ }^{10}$ So that from these signs it can give us an indication that

${ }^{6}$ Al-Așfahānīi, Abal- Qāsim al-Husain bin Muhammad al-Ma'rf bi al-Rāgib w.502 H). alMufradāt fí Garīb al-Qur'ān, yang di-rāji' oleh Wā'il Aḥmad 'Abd al-Raḥmān, (al-Qāhirah-Mishr: alMaktabat al-Tawfiqiyyat, 2003), h. 372-373.

${ }^{7}$ Abd. Muin Salim Mardan \& Achmad Abu Bakar, Metodologi Penelitian Tafsir Maudu'iy (Jakarta: Penerbit, Pustaka Mapan, 2012), h. 29.

${ }^{8}$ Firdaus, "Musyawarah dalam Perspektif Al-Qur'an" Al-Mubarak Jurnal Kajian Al-Quran \& Tafsir 4 (2), 2019, h. 72.

${ }^{9}$ Departemen Pendidikan dan Kebudayaan, Kamus Besar Bahasa Indonesia (Cet.X; Jakarta: Balai Pustaka, 1999), h. 677.

${ }^{10}$ Firdaus, "Musyawarah dalam Perspektif Al-Qur'an" Al-Mubarak Jurnal Kajian Al-Quran \& Tafsir Volume 4, No. 2, 2019, h. 73. 


\section{Al-Qur'an Insights About MusyāWarāH \\ (A Study of Maudhu'iy Commentary on Deliberation)}

Allah gave us hint for his servant in solving all problems, even at the level of the smallest group (family) should do something because of a joint decision between husband and wife.

\section{Syawir QS Āli 'Imrān/3:159}

QS Ali Imran verse 159, where the text of the verse above contains orders to the Prophet Muhammad. in order to consult with his friends, as reflected in the clause Tَشَارِزْهُمْ الأمْرِ the sentence gَ فَشَاوِرْهُمْ meaning that the order is only addressed to the Prophet. However, commentators explain that even though the command is single and only addressed to the Prophet, it is an order to do deliberation is addressed to everyone.

Viewthey are very logical because the Prophet. In this context, apart from being a prophet, he also carries out his main duties as the Messenger of Allah who has people so that he has the obligation to convey, inform that the content is addressed to all mankind, including important matters related to deliberation. If the Prophet If you just conduct deliberations in deciding a case, then the people must also follow it, even more so if it is understood that the Prophet SAW. Even those who are infallible are still holding deliberations in deciding a case, especially their people who are far from infallible. In this context, the word syawir is the keyword to be analyzed. ${ }^{11}$ The word syaawir is the imperative form of the verb syaawara-yusyaawiru which has the form of masdar from the word deliberation. The main meaning of the word is to show and offer something and take it.

\section{Shuara QS Ali Imran verse 159}

QS Ali Imran verse 159 explains the text of the verse in it contains orders to the Prophet. to consult with his friends, as reflected in the clause الأمَرِ اوِرْ هُمْ

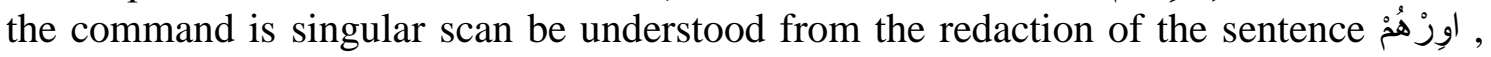
meaning that the order was only addressed to the Prophet. However, commentators explain that although the command is single and only addressed to the Prophet, the command to conduct deliberation is addressed to everyone. ${ }^{12}$

View they are very logical because the Prophet. is the leader of the ummah who is obliged to convey the content of the verse to all mankind, including deliberation. If the Prophet If you just conduct deliberations in deciding a case, then the people must also follow it, even more so if it is understood that the Prophet SAW. those who are ma'sum still hold deliberations in deciding a case, especially their people who are far from being human. In this context, the word syawir is the keyword to be analyzed. The word syaawir is an imperative form of the verb syaawara-yusyaawiru which has the masdar form of the word deliberation. The main meaning of the word is to show and offer something and take it. ${ }^{13}$

\footnotetext{
${ }^{11}$ Abd. Muin Salim Mardan \& Achmad Abu Bakar, Metodologi Penelitian Tafsir Maudu'iy (Jakarta: Penerbit, Pustaka Mapan, 2012), h. 29.

${ }^{12}$ Abd. Muin Salim Mardan \& Achmad Abu Bakar, Metodologi Penelitian Tafsir Maudu'iy (Jakarta: Penerbit, Pustaka Mapan, 2012), h. 30.

${ }^{13}$ Abd. Muin Salim Mardan \& Achmad Abu Bakar, Metodologi Penelitian Tafsir Maudu'iy (Jakarta: Penerbit, Pustaka Mapan, 2012), h. 30.
} 
QS al-Syüra verse 38 describes how the Ansar group were willing to defend the Prophet. formulate, negotiate and agree on it by means of deliberation conducted at the house of Abu Ayyub al-Ansari. The term verse بَيْنَهُ describes that they negotiate something with gentleness and careful consideration, not merely canceling the obligation. So that in its implementation it should not seem rushed, and not only present to witness the goodness but there are individual efforts in every problem

The verse is contained in Surah Ash-Shura, which means deliberation. This proves how important deliberation is in overcoming every problem of life faced, especially problems related to social society. ${ }^{14}$ From the three terms of deliberation in the Qur'an, it is concluded that deliberation is an effort to find benefits in making decisions fairly through exchange of ideas, dialectics and negotiations.

B. The Object of Deliberation, The Participants of The Deliberation, and The Principles of Deliberation in The Perspective of The Qur'an

In To understand further related to the general description of the deliberation, the following description will explain:

1. Object discussion

The term deliberation in the Qur'an with its derivational forms is mentioned three times, namely: QS al-Baqarah verse 233; QS Ali 'Imran verse 159; and QS alSyu>ra' verse 38. The three verses in the Qur'an provide information related to the object of deliberation, namely:

a. Family, as stated in QS. al-Baqarah verse 233

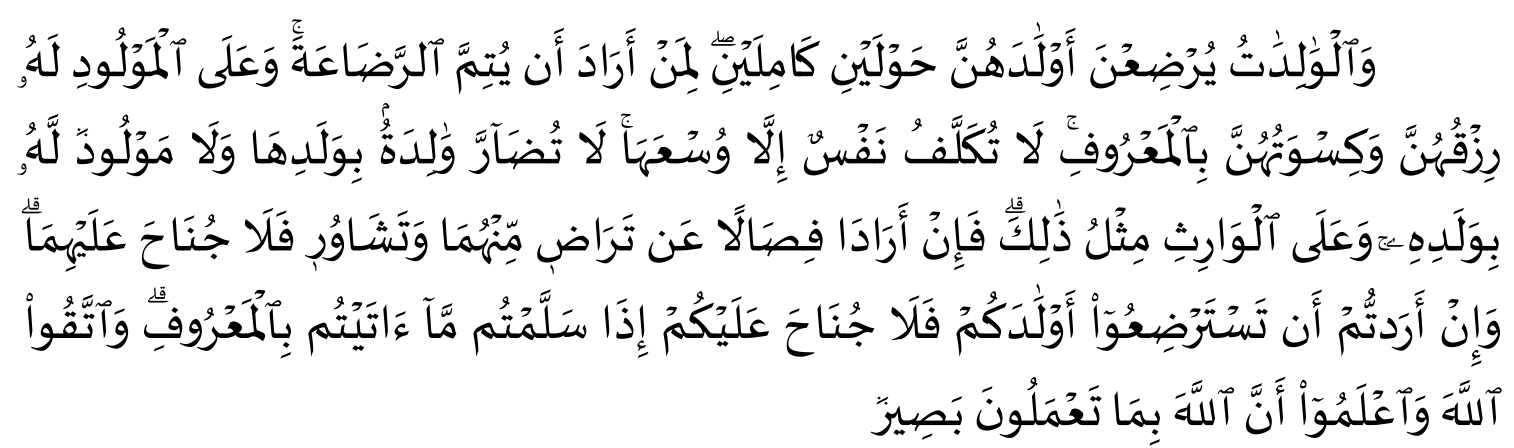

The translation:

"Mothers should breastfeed their children for two whole years, that is, for those who want to complete breastfeeding. And the duty of the father to feed and clothe the mothers in the Maruf way. Someone not burdened but according to ability levels. Let not a mother suffer misery because of her child and a father because of his child, and the heir is obliged to do so. If both want to wean (before two years) with their willingness and deliberation, then there is no sin on either of them. And if you want your child to be nursed by someone else, then there is no sin for you if you give the proper payment. Fear Allah and know that Allah is All-Seer of what you do."

${ }^{14}$ Firdaus, "Musyawarah dalam Perspektif Al-Qur'an" Al-Mubarak Jurnal Kajian Al-Quran \& Tafsir Volume 4, No. 2, 2019, h. 72. 


\section{Al-Qur'an Insights About MusyāWarāH \\ (A Study of Maudhu'iy Commentary on Deliberation)}

As in QS. al-Baqarah verse 233 gives us a hint that the most basic object of deliberation is within a small scope, namely the family, even if we look at the current adult context where we are still familiar with patriarchal ways in society. This is in contrast to the information contained in the Al-Qur'an which does not make women in households who only receive orders from men but career women have the right to make their choice in breastfeeding their children through deliberation in the family, although it cannot be denied about the virtues of women who breastfeed. her own child, but it can be interesting here because even important things that are generally the mother's nature must also be determined through deliberation.

This is also explained in Tafsir al-Misbah M. Quraish Shihab also describes that the verse under certain conditions the child is no longer breastfeeding his parents (weaning) but this must be passed with careful consideration, with various alternative solutions that must be provided when referring to the word deliberation in the verse We understand that deliberation must be carried out on the basis of seeking the common good without harming both parties, and the choices made do not harm the mother, father, heirs and most importantly the rights to the child's growth and development. ${ }^{15}$

Syekh Muhammad Abduh gave a description regarding this matter which explained that both parents have joint responsibility in determining whether the child will continue breastfeeding until the breastfeeding period is complete, which is 2 years, or terminated beforehand. Meanwhile, al-Qurtubi, explains that the context of deliberation is a category of ijtihad. The view of Sheikh Rasyid Rida is that this verse contains educational value. ${ }^{16}$

What is meant by educational value is how to build communication patterns in the family regarding basic issues that should be solvedthrough wise means, namely deliberation. This is intended as a form of habituation that deliberation is a concept of interaction, exchange of ideas in determining good things through good methods. If things are basic in the family, what else is there for the larger context related to groups, communities, nations and states which are much more complicated than the family sphere.

2. Public General / public, QS Ali Imran, 3:159.

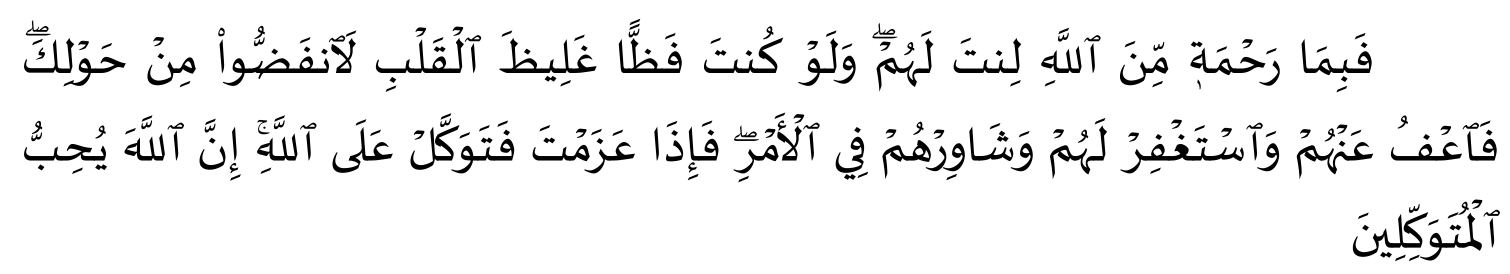

The translation:

"So it is by the mercy of Allah that you are gentle with them. If you were hardhearted and harsh-hearted, they would have distanced themselves from those

\footnotetext{
${ }^{15}$ Abd. Muin Salim Mardan \& Achmad Abu Bakar, Metodologi Penelitian Tafsir Maudu'iy (Jakarta: Penerbit, Pustaka Mapan, 2012), h. 30.

${ }^{16}$ Muhammad Rasyid Riḍā' (w.1865 M), Tafsìr al-Qur'ān al-Hakìm/Tafsìr al-Manār, Juz II, (Cet.II; Kairo: Dār al-Kutub al-Ilmiyyāt, 1426 H/2005M), h. 83.
} 
around you. Therefore forgive them, ask forgiveness for them, and consult with them in this matter. Then when you have made up your mind, then put your trust in Allah. Verily Allah loves those who put their trust in Him."

Ibrahim bin 'Umar explained that the verse is editorially related to the Prophet Muhammad. to be gentle and always put forward good ways in solving all kinds of problems in groups and communities. In addition, this is also a guide for all humans, especially for leaders without exception to use wise ways in solving various kinds of problems, including by prioritizing deliberation in determining decisions to reach consensus in their government. ${ }^{17}$

Meanwhile, if we review from Asbabun nuzul the revelation of this verse because at that time there were friends who were not disciplined when fighting which caused the Prophet's troops to be forced to accept defeat in the Uhud war. So that this verse came down as a guide for the Messenger of Allah, to forgive and always be gentle, forgive the undisciplined friends and still invite them to consult to deal with the problem.

a. The Believer Community, QS al-Shura' verse 38 .
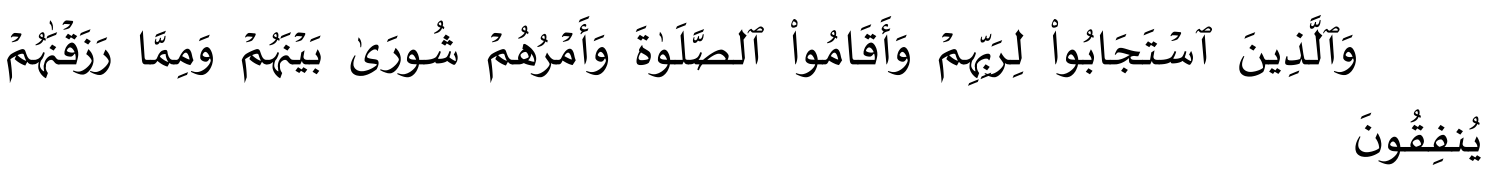

The translation:

"And those who accept (obey) the call of their Lord and establish prayer, while their affairs are (decided) by deliberation between them; and they spend part of the sustenance We have given them."

Abd. Muin Salim Mardan \& Achmad Abu Bakar provide an explanation in the meaning of this verse that there is eternal pleasure that will be given to people who carry out prayer consistently and sincerely and sincerely, as well as those who always prioritize deliberation as a form of interaction in determining decisions on an issue and those who accept the results of the deliberation decision. ${ }^{18}$

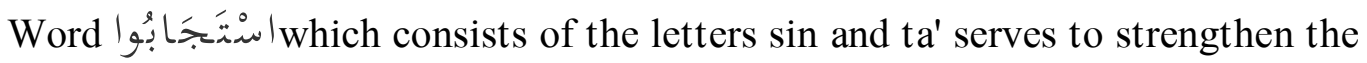
acceptance (istajabah). Where there is a very sincere acceptance, without doubt and hatred. There are also scholars who interpret it in the context of a special acceptance, such as what was done by the Ansar figures in (Yastrib)/Medina at that time, when they welcomed/accepted the Muhajirin who had just migrated from Mecca. While the

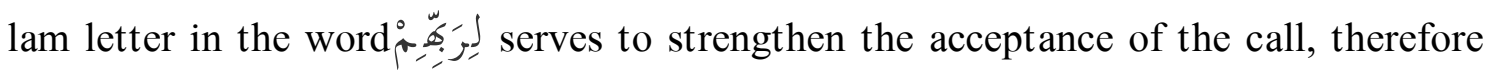
the author tries to explain it and emphasizes that what is meant is in the sense of "really fulfilling the call of their Lord".

${ }^{17}$ Ibrāhīm bin 'Umar Biqā'i, Burhānuddìn Abal-Husain al-Nazmal-Durar fì Tanāsub al-Āyāt wa al-Suwar, (al- Qāhirat: Dār al-Kutub al-Islāmī, 1413 H/1992 M), h. 213

${ }^{18}$ Abd. Muin Salim Mardan \& Achmad Abu Bakar, Metodologi Penelitian Tafsir Maudu'iy (Jakarta: Penerbit, Pustaka Mapan, 2012), h. 32. 


\section{Al-Qur'an Insights About MusyāWarāH \\ (A Study of Maudhu'iy Commentary on Deliberation)}

The term "syürä"' is based on the term syaur, which means "to take and issue the best opinion by arguing against one opinion with opinion another. The term is inspired by the phrase " العسل" syirtu al-'asal, which means (I take out honey from the container.) This becomes very relevant to the description of the definition above about associating expressing an "opinion" with taking honey. Which in this context, deliberation means "trying to reach the honey (goodness and truth) wherever it is found, or in this case whoever is right will be accepted regardless of who conveyed it, this is closely related to objectivity in deliberation, so that the concept of deliberation relates to taking the most correct opinion not about who conveys it.

For term grovide an indication that the people who conduct deliberations related to a problem should be in accordance with their field/specialization and are within their authority. So that related to mahḍah/pure worship in this case it is God's prerogative to determine it, and these things are not included in matters that can be discussed because the patron is final, this is related to the pillars in the implementation of mahdah worship which cannot inviolable again even through deliberation. Why? Because in that context humans have no authority in these matters. As with certain matters of a confidential nature, unauthorized persons do not need to be involved in deliberation on this matter. ${ }^{19}$

In the context of deliberation, the Qur'an provides explicit boundaries regarding how the form and form of shura'. so it is understood that in the concept of shura, the door of interpretation is still very open to produce ijtihad in drafting a contextual deliberation concept in accordance with the value system and developments prevailing in society. And it is important to know that when this verse was revealed, it was in a period in which an Islamic society with political power had not yet been formed, or in other words, the State of Medina which was led by the Prophet Muhammad was not yet formed. The revelation of the verse describing the shura' in the Meccan period.

While in the sentence إه I Ordered that the Muslims improve their work ethic in the fields they are engaged in to obtain maximum results, with maximum results, the potential for sharing can be realized to always behave generous because it has advantages in that regard, the verse also provides information for us not to narrowly understand God's sustenance which is not limited to only material issues but there are many other things that we need to know, but apart from the issue of the breadth of perspective in understanding Allah's sustenance, there are other interpretations. explicitly, that this verse is related to the characteristics of believers, which include: a) obedience and obedience to Allah swt.,b) perform the prayers; c) revive deliberation, d) be generous. ${ }^{20}$

Ibn Taymiyyah expounds that the Verse relating to the believer will be rewarded even more favorably with Allah. This verse also doesn't come down forgave praise to the Muslims in Medina (Anșār) at that time, who had been willing to defend the Prophet Muhammad. and agreed on this through deliberation, which at that time

${ }^{19}$ Abd. Muin Salim Mardan \& Achmad Abu Bakar, Metodologi Penelitian Tafsir Maudu'iy, (Jakarta: Penerbit, Pustaka Mapan, 2012), h. 35.

${ }^{20}$ M. Quraish Shihab, Ensiklopedia Al-Qur'an: Kajian Kosakata. (Jakarta: Lentera Hati, 2007), h. 967 . 
was carried out at the house of Abu Ayyub al-Anșāin. It should be noted that deliberation can be carried out in general by prioritizing the principle of taking honey in the process, namely holding fast to the most correct opinion, not about who said it. ${ }^{21}$

\section{The Principles of Deliberation in the Qur'an}

QS. Ali Imran verse 159 provides an illustration regarding the three attitudes that were coherently ordered to the Prophet SAW that must exist before holding a deliberation. These three attitudes must be owned by the person who will participate in the deliberation so that its implementation can run according to expectations. This basic attitude can be seen in QS. Ali Imran verse 159, namely:

\section{Gentleness and Not Extreme}

For every participant in the deliberation, should have a gentle attitude and as much as possible avoid harsh words and can offend other deliberation participants, not extreme and not stubborn. If this attitude is not maintained and not practiced in the deliberation, then the other deliberation participants may leave the ongoing deliberation. Even such deliberation can lead to disputes and contradictions, so that the purpose of deliberation in order to produce bright ideas or good and noble opinions cannot be achieved. This gentle attitude can be understood from the clause of the verse:

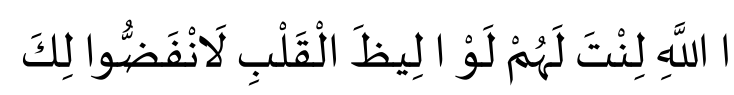

According to Muhammad Abduh as explained by his student Muhammad Rashid Rida that the above verse was revealed regarding a war in which there was a difference of opinion between the Prophet SAW and some of his companions, resulting in the weakening of the spirit of some of them. and at the same time, the polytheists emerged, so that the Prophet and his companions suffered defeat in the war, namely the battle of Uhud. However, the Prophet Muhammad remained gentle in his intercourse with them.

On the eve of the battle of Uhud, the Prophet (PBUH) gathered his companions to discuss ways or strategies to deal with enemies who are moving from Makkah towards Medina. In the deliberation, there are two strategies that can be chosen to deal with the enemy, namely offensive and defensive. Personally, the Holy Prophet chose to be on the defensive and remained in the city of Medina. However, his friends, especially the youth, urged the Muslims under the leadership of the Prophet to come out to meet the enemy. This opinion received the support of the majority, so the Prophet agreed to it. Inwar During this time, the Muslims suffered defeat and no less than seventy of the companions of the Prophet Muhammad died on the battlefield.

2. Open-minded, open and forgiving attitude

This attitude must be owned by those who participate in deliberation because in deliberation there are often differences of opinion, even disputeand quarrels between

${ }^{21}$ Ibn Taimiyyah, Syaikh al-Islām Taqiyuddin Abū al-'Abbas Aḥmad $(738 \mathrm{H})$, al-Tafsīr alKāmil, Juz VII, di-tahqqīq Abū Sa'id 'Umar al-Amrawī, (Baer•t: Dār al-Fikr, 1423 H/2002 M), h. 211. 


\section{Al-Qur'an Insights About MusyāWarāH \\ (A Study of Maudhu'iy Commentary on Deliberation)}

them. With this attitude, disputes and quarrels can be muted. ${ }^{22}$ An open-minded, tolerant and forgiving attitude to each other will give birth to a clear mind, so that they can take wrongone of the best of them. Clause verse اعْ in QS. Ali Imran: 159 is the basis and indication that apologizing to those who have issued harsh words and statements that can offend feelings in deliberation is an attitude that must be owned and practiced.

3. Humble and Beg for Forgiveness

This attitude can be understood from the clause Imran: 159. The clause of this verse commands to ask forgiveness for themto Allah SWT, for matters relating to His rights, so that the outpouring of His love and care can be realized to the fullest (Al-Alusy, 1993: 166).

\section{Attitude of Determination and Tawakkal}

This attitude is carried out after the deliberation has been carried out and has producea decision. This attitude is reflected in the clause inil اللَّهِ لَى لَ According to Muhammad Rasyid Rida, this verse explains that if the deliberation has been carried out and has resulted in a decision that has been chosen by the forum, then all participants in the deliberation must be determined to carry it out, then put their trust in Allah SWT. (Muhammad Rashid Rida: 205). The decision must be implemented wholeheartedly, even though the decision differs from the opinion of some of the deliberation participants. ${ }^{23}$

\section{Benefits Deliberation in The Perspective of The Qur'an}

The terms of deliberation and their forms of derivation are contained in: QS alBaqarah verse 233; QS Ali Imran verse 159, and QS al-Syūra verse 38; contains content that gives us a related picture of the urgency of deliberation in the perspective of the Al-Qur'an, as for the benefits according to the references of the three verses, namely:

1. Forming the character of a wise leader in humans according to their nature. This is interpreted because in the verses of deliberation it is emphasized that the people involved in the deliberation should be gentle and avoid harsh words, as well as stubbornness in the results that have been decided.

2. People who are in deliberation should try to forgive anyone in the deliberation forum because there is a huge potential for unwanted things to happen if something is too much when arguing.

3. People in deliberation should realize that the brightness or sharpness of analysis is not enough, as the opinion of William James, who wrote that: "Reason is amazing, it is able to cancel one argument with another argument. This will be able to lead us to doubts that shake our ethics and

\footnotetext{
${ }^{22}$ M Makbul, Ismail, I., Ismail, W., \& Ahmad, L. O. I, The Effect of Emotional Intelligence and Spiritual Intelligence on Learning Outcomes of Islamic Religion and Characteristics of Students at SMA Negeri 5 Makassar IJSSHR 42020 588-595.

${ }^{23}$ Firdaus, Musyawarah dalam Perspektif Al-Qur'an, Al-Mubarak Jurnal Kajian Al-Quran \& Tafsir 4, No. 2, 2019, 77-79.
} 
values of life". If so, we still need "something" in addition to "reason". It's up to you, what is the name of that "something". This is related to a person's ability to be fair and gentle and to use the inner aspect in deliberation while always relying on Allah for whatever results from the deliberation.

4. Get closer to Allah swt. To achieve the best results when deliberation, submission to Allah is very decisive. So the deliberation should be accompanied by a request for magfirah and His forgiveness in accordance with what is confirmed in QS Âli 'Imran verse 159 above, "wa istagfirlahum".

5. Solve various problems both for yourself, family, groups and society, nation and state

6. Deliberation requires a healthy exchange of ideas with other participants, thus giving birth to new ideas.

7. Deliberations, if understood and carried out according to their patrons, will not blame each other in acting between participants because they feel they are the most correct in their arguments.

8. In the deliberations of proposals, ideas that are not accepted are not seen as despicable. $^{24}$

9. Decisions made with a lot of thought tend to be better if they are decided alone because many perspectives make a whole concept that will be used to solve problems. ${ }^{25}$

\section{CONCLUSION}

Deliberation is a forum to express opinions in solving a problem. The opinions expressed by the participants of the deliberations, the one that is most appropriate is chosen, regardless of who expresses the opinion. The objects of the deliberation include the family, the general public/public, the Believer Community, the participants of the deliberation and the practice of deliberation, the deliberation has always experienced dynamics in its implementation since the time of the Prophet, Khulafaur Rasyidin then to the current era. The benefits of deliberation are many but lead to the common good of humans both in household life, society, nation, and state, in accordance with its meaning as a good method to issue something good for the achievement of human justice in all aspects of life.

${ }^{24}$ Ahmad Syafi'I Ma'arif, Islam dan Masalah Kenegaraan (Jakarta: LP3ES, 1985), 49-50.

${ }^{25}$ Bahruddin, Musyawarah dalam al-Qur'an: Suatu Kajian Tafsir Tematik (Disertasi) (SamataGowa: PPS UIN Alauddin Makassar, 2015), h. 161-162. 


\section{REFERENCE}

Amir, A., Khalid, M. R., Garancang, S., \& Kasim, A. Bentuk-Bentuk Takrār dalam AlQur'an menurut Tinjauan Balagah (Studi Pada Juz Amma). Jurnal Diskursus Islam, 5(3), 498-526.

Bahruddin, Musyawarah dalam alquran: Suatu Kajian Tafsir Tematik (Disertasi) (Samata-Gowa: PPS UIN Alauddin Makassar, 2015.

Biqā'ì, Ibrāhīm bin 'Umar, Burhānuddin Abal-Ḥusain al-Naẓmal-Durar fî Tanāsub alĀyāt wa al-Suwar, (Jilid I-XXII. Cet.II; al- Qāhirat: Dār al-Kutub al-Islāmī, $1413 \mathrm{H} / 1992 \mathrm{M})$

Departemen Pendidikan dan Kebudayaan. Kamus Besar Bahasa Indonesia Jakarta: Balai Pustaka, 1999.

Firdaus, "Musyawarah dalam Perspektif Al-Qur'an" Al-Mubarak Jurnal Kajian AlQuran \& Tafsir Volume 4, No. 2, 2019.

Ka-anga, M., \& Hamzah, H. Metode Ijtihad Lembaga Majlis Agama Islam Provinsi Pattani Thailand Selatan. Jurnal Diskursus Islam, 7(2), 314-334.

Ma'arif, Ahmad Syafi'i, Islam dan Masalah Kenegaraan, Jakarta: LP3ES, 1985

Makbul, M. Ismail, I., Ismail, W., \& Ahmad, L. O. I, The Effect of Emotional Intelligence and Spiritual Intelligence on Learning Outcomes of Islamic Religion and Characteristics of Students at SMA Negeri 5 Makassar IJSSHR 4 2020 588-595.

Mardan, Abd. Muin Salim \& Achmad Abu Bakar, Metodologi Penelitian Tafsir Maudu'iy, Jakarta: Penerbit, Pustaka Mapan, 2012.

Riḍā' Muhammad Rasyid (w.1865 M), Tafsìr al-Qur'ān al-Hakīm/Tafsìr al-Manār, Juz II, Kairo: Dār al-Kutub al-Ilmiyyāt, 1426 H/2005M .

Said, Muh. "Metodologi Penafsiran Sufistik: Perspektif Al-Gazali." Jurnal Diskursus Islam 2.1 (2014): 142-168.

Shihab, M. Quraish Ensiklopedia Alquran: Kajian Kosakata, Jakarta: Lentera Hati, 2007.

Taimiyyah, Ibn Syaikh al-Islām Taqiyuddin Abū al-'Abbas Ahmad $(738 \mathrm{H})$, al-Tafsir al- Kämil, Juz VII, di-tahqqìq Abū Sa'id 'Umar al-Amrawì, Baer॰t: Dār al-Fikr, $1423 \mathrm{H} / 2002 \mathrm{M}$. 